\title{
编者按
}

\section{前言: 庆祝河北大学化学学科创立70周年}

河北大学化学学科前身是1951年创办于天津的国立津沽大学师范学院化学系(1952年改建为天津师范学院 生化系). 1958年, 天津师范学院改为天津师范大学, 化学系成立了401 407等7个科学研究组, 所研制的产品耐烧 蚀硼酚醛树脂用于我国第一颗人造卫星及“运七”飞机. 同年, 化学系黄惠芝被评为全国三八红旗手和天津市劳动 模范, 并受到了毛泽东主席的亲切接见. 1960年, 天津师范大学改建为综合性大学并定名河北大学后, 化学系也以 崭新的面貌快速发展，并逐步由师范类的学科向综合大学的理科过渡，招生范围由全国改为以河北省招生为主， 学制改成5年制的化学本科. 1970年河北大学由天津迁到保定. 1977年恢复高考后, 化学本科恢复, 学制改为4年. 1985年河北大学化学系率先在全国建立阻燃材料研究室, 分析化学被批准为河北省首批重点学科; 1986年, 分析 化学获得硕士点, 成为河北省第一个分析化学硕士点. 1998年获批分析化学博士点, 成为我国地方高校分析化学 第一个博士点. 2000 年11月学校进行院系调整, 化学系更名为化学与环境科学学院. 化学学科步入了持续、快速 发展的轨道.

化学学科现有 1 个化学一级学科博士后科研流动站、 1 个化学一级学科博士学位授权点和 1 个国家级化学一 流专业建设点; 拥有 1 个“药物化学与分子诊断” 教育部重点实验室、 1 个高分子材料与加工技术国家地方联合工 程实验室、 1 个国家级化学实验教学示范中心、 3 个省级重点实验室(中心)和 1 个河北省药物创制协同创新中心. 2005 年, 化学学科被列为河北省 24 个高校强势特色学科(群)进行重点建设; 2012年成为河北省率先进入ESI全球前 $1 \%$ 行列的化学学科，2013年获批河北省国家重点学科培育项目，2016年列入河北省“世界一流学科”建设项目. 2019年, 材料科学学科首次进入ESI全球排名前 $1 \%$ 行列.

化学学科秉承“团结求是、探索创新”的院训, 形成了学科梯队合理、学科分布全面的师资队伍. 现有专任教 师 98 人，其中博士生导师 32 人，教授 54 人，拥有中国工程院院士、教育部“长江学者”特聘教授、国家杰出青年科 学基金获得者、全国优秀教师等省部级以上人才称号教师 35 人，拥有教育部“长江学者和创新团队发展计划”创 新团队、“河北省巨人计划创新团队”和“河北省自然科学基金创新研究群体”等高层次科研团队．目前，化学专 业、材料化学、高分子材料与工程三个专业在读本科生 965 人, 硕士研究生 503 人, 博士研究生 68 人. 研究生按一 级学科招生, 拥有无机化学、有机化学、物理化学、分析化学、高分子化学与物理、化学生物学共 6 个二级学科 博士点. 化学学科自创立以来培养了大批化学专业人才. 近年来, 毕业生一次就业率均在 $95 \%$ 以上. 河北大学化学 学科已成为省内外化学与材料领域科学研究和人才培养的重要基地.

化学学科秉承“立足国家重大战略、服务区域发展需求、瞄准学科发展前沿”的建设理念，在二级学科方向 基础上, 注重学科交叉与融合、理论创新和应用基础研究相结合, 形成了“创新药物”、“绿色催化”、“功能材料” 和“分离检测” 4 个特色鲜明的研究方向. 近五年, 获批各类纵向科研项目总计 165 项, 其中, 国家自然科学基金 37 项; 省部级项目共计99项，包括国家水体污染控制与治理科技重大专项 2 项，河北省杰出青年科学基金9项，河北省自 然科学基金重点项目 4 项, 河北省“巨人计划”创新团队项目 1 项, 河北省教育厅创新百人计划项目 3 项. 获得包括河 北省自然科学一等奖、科学进步奖一等奖在内的省部级科研奖励 6 项.

化学学科注重本科生创新创业能力培养. 学生先后荣获全国“挑战杯”大学生课外学术科技作品竞赛一等奖

引用格式: Zhang JC. Preface: Celebrating the 70th Anniversary of Chemical Sciences in Hebei University. Sci Sin Chim, 2021, 51: 1113-1114, doi: 10.1360/SSC2021-0208 
1项、二等奖3项、三等奖7项，省级特等奖4项、一等奖7项; 荣获“中国青少年科技创新奖”1项; “创青春”全国大 学生创业大赛金奖1项; 获得第七至十三届全国大学生化工设计竞赛二等奖, 河北省第五届“互联网+”大学生创新 创业大赛金奖1项; 承担大学生创新创业训练项目国家级7项、省级14项. 2014年荣获全国首届百强大学生“小平 科技创新团队”.

值此河北大学建校 100 周年暨化学学科创立70周年之际, 我们很荣幸在《中国科学: 化学》组织出版该专刊. 本期专刊汇集了16篇论文和综述, 集中介绍了河北大学化学学科近年来在无机化学、有机化学、分析化学、物 理化学、高分子化学与物理、理论计算化学、纳米与能源环境化学等领域的研究进展.

我们期盼与国内外化学家相互交流, 进一步加强合作, 共同促进化学及相关学科的发展. 借此机会, 我们向所 有支持和帮助河北大学化学学科发展的各界人士致以崇高的敬意和由衷的感谢!

张金超 河北大学化学与环境科学学院

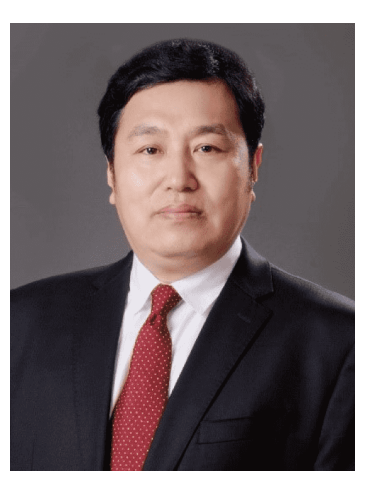

张金超，2001年于浙江大学获得博士学位，2001 2003年在北京大学做博士后研究， 2003 2006年在香港城市大学做高级访问学者. 现为河北大学教授、博士生导师, 河 北大学化学与环境科学学院院长、药物化学与分子诊断教育部重点实验室常务副主 任、中国生物物理学会纳米生物学分会副主任、河北省政府特殊津贴专家. 主要研 究领域为纳米医学与分子诊疗. 迄今为止, 在SCI收录期刊发表论文 150 余篇; 获授权 中国发明专利 20 余项, 先后主持国家“重大新药创制”科技重大专项、国家自然科学 基金、河北省自然科学基金杰出青年基金等20余项课题. 作为第一完成人，先后获 河北省自然科学一等奖(2019年)和二等奖(2014年)各一项. 